\title{
A deliberation on recent legal cases and judgments of the International Court of Justice on environmental disputes
}

\author{
S. Zarei ${ }^{1} \cdot$ S. A. Poorhashemi ${ }^{1} \cdot$ M. Pournouri ${ }^{2}$
}

Received: 17 December 2014/Revised: 14 March 2015/Accepted: 25 April 2015/Published online: 16 June 2015

(C) Islamic Azad University (IAU) 2015

\begin{abstract}
Both national and international judgments and judicial precedents play an important role in the development of legal regimes. In the light of judgments and judicial precedents, the administration of justice and judicial security can be measured in every legal system. In this context, the International Court of Justice and other international judicial and arbitral bodies have an important role to play in the development of international law, particularly in international environmental law. In addition, judgments and judicial precedents of international courts, especially the International Court of Justice can affirm new legal rules and principles that can contribute to the development of international environmental law. This research through content analysis attempts to analyze the capacity and capability of new international judgments and judicial precedents of the International Court of Justice on environmental issues in influencing the development of environmental law. For this purpose, this study attempts to analyze five recent legal cases of the International Court of Justice. It also provides guidelines for applicable solutions by identifying legal gaps and existing inefficiencies.
\end{abstract}

Keywords International environmental law · Judgments and judicial precedents - Environmental protection . Development of environmental law $\cdot$ International Court of Justice $\cdot$ Environmental disputes

S. A. Poorhashemi

Ahashemy@yahoo.com

1 Department of Environmental Law, Faculty of Environment and Energy, Science and Research Branch, Islamic Azad University, Tehran, Iran

2 Faculty of Law, Central Tehran Branch, Islamic Azad University, Tehran, Iran

\section{Introduction}

Emerging international environmental law field as a new branch of the international public law could take advantage of soft law to its own development which had no position in the classical international law. On the other hand, international environmental law could show how this soft law can be converted into codified and reliable principles of law (Sands 2003).

In light of recent developments in this legal field, the right to a healthy environment, common heritage of mankind, rights of future generations, right to development and the concept of sustainable development were expanded as examples of environmental human rights and were adopted as the national and international legal norms that were recognized by international judgments and judicial precedents (Plator 1994).

The role of international judgments and judicial precedents in environmental protection were considered since scientific progress and development of new technologies put the environment at a greater risk. By growing environmental issues and expanding different activities in this field, many disputes were raised in this context (Sands 2008). The emergence of international environmental disputes showed the absence of peaceful settlement of dispute system in this area and revealed the fact that existing international legal regimes cannot be responsive to such disputes (Waldock 1948). The main reason has been stated is specialization of environmental issues; hence, existing international courts do not have necessary expertise to resolve these types of disputes (Thirlway 2010).

Some international judicial bodies such as International Court of Justice (ICJ) have focused on some aspects of environmental disputes. However, these kinds of disputes are so extensive and complex in which structures and goals 
of international courts do not permit a full and effective judicial proceeding (Gross 1972); in many cases, these courts refuse to establish their jurisdiction to proceed environmental issues or focus only on particular aspects of such disputes like Gabcíkovo-Nagymaros project in 1997 (Avgerinopoulou 2003). On the other hand, lots of judgments and judicial precedents have addressed the environmental issues, either directly or indirectly, but here an attempt will be made to refer to the more important environmental disputes.

\section{Pulp Mills on the River Uruguay case, Argentina versus Uruguay (May 4, 2006)}

\section{Statement of facts}

The two-year dispute between Argentina and Uruguay on the coast border of Uruguay River on issuance of permission to build pulp mills along the river led Argentina to file a lawsuit against Uruguay on May 4, 2006. Argentina in its application accused Uruguay of violating its obligations according to the Statute of the River Uruguay (Pulp mills on the River Uruguay, Application instituting proceedings 2006a).

Under the 1961 Agreement, the Parties agreed to establish a system based on development of common regulatory standards for the safety of navigation; determine the shipping regime; adopt rules for dredging and floatation in accordance with Article 6; provide mutual facilities to assess the hydrographic and other related studies of the river; adopt rules and regulations relating to protection of living resources and finally adopt rules and regulations for preventing water pollution in both countries. This legal regime subsequently established in Statute 1975 in the form of Administrative Commission of the River Uruguay (CARU). This Statute is a treaty between the Governments of Argentina and Uruguay that have signed on February 26, 1975. The purpose of this Statute is the establishment of a common mechanism for equitable and reasonable utilization of the River Uruguay which is a trans-boundary river between the two countries. As specified in Article 7 of the Statute, the Commission is responsible for regulations and coordinations (Statute of the River Uruguay 1975).

In this case, the Government of Argentina claims that the Government of Uruguay with the construction of two mills on the banks of the River Uruguay, near the city of Gualeguaychù in Argentina, has violated the Statute of the River Uruguay and has caused damage to the environment of the river and its coastal zone (Pulp mills on the River Uruguay, Indication of provisional measures 2006b).

\section{Court judgment}

Finally, ICJ on April 20, 2010, delivered its judgment in the case concerning pulp mills on the River Uruguay (Argentina vs. Uruguay). The Court after reviewing the substantive and procedural aspects of the legal case reminded the Parties about obligation to cooperation, negotiation and environmental protection (Pulp mills on the River Uruguay, Summary of the Judgment 2010).

Although the Court condemned Uruguay Government to violate the procedural formalities to inform the Government of Argentina, it substantively due to lack of evidence on environmental damage did not convict Uruguay. In this judgment, the Court relied on several principles of international environmental law, including the "principle of burden of proof is on the plaintiff." The Court extended this principle to the field of international environmental law and obliged the Argentina to provide documentary evidence on violation of the Statute. The Court imposes this principle on the scope of Erga Omnes obligations. Next, the Court examines the nature of the Administrative Commission of the River Uruguay and considers it necessary for the implementation of the cooperation obligation referred to in Article 1 of the Statute. According to the Court, this Statute has presented substantive obligations in broadway and the procedural obligations in restrictive way. These two types of obligations complement each other, so the Parties could achieve the treaty objectives. Argentina suggests several substantive obligations to prove the violation of its obligations. The Court did not assume Uruguay actions contrary to the Statute. These actions included obligation to equitable and reasonable utilization, obligation to prevent ecological changes, obligation to inform the Parties and more. In the following, the practice of the Court in this case will be evaluated (Pulp mills on the River Uruguay, Summary of the Judgment 2010).

\section{Judgment analysis}

In this case, the Court considered various international environmental law issues. The judgment affirms the principle of equitable and reasonable utilization that is mentioned in Article 1 of the Statute of the River Uruguay. The Court's interpretation of such principle leads into sustainable development and protects the river environment. According to the Court, this is the principle in which the Parties are obliged to prevention of pollution and protection of aquatic animals. However, the Court considers the principle of equitable and reasonable utilization as the core of Cooperation Commission activities. Another principle that the Court emphasized is the information principle that is one of the recognized principles of international environmental law. In this case, the Court has made a 
distinction between informing the Cooperation Commission and notifying the Parties. The Court considers information principle, as the continuation of the prevention principle in which having trans-boundary environmental impact is necessary to this obligation. But information and notification are required, when the Commission identifies possible environmental risks (Merkouris 2010).

The Court with the implied consent of the Statute has somehow accepted representative of the Parties in local environmental protection, while the real beneficiaries are residents (Salmenkari 2007).

Albeit the principles of information and environmental impact assessment have been predicted with the aim of environmental damage prevention, in this case the Court deals with the issue of prevention separately. Article 17 of the Statute refers to the prevention of river pollution. The Court recognizes this principle as part of customary law and knows its roots in obligation to due diligence on territory protection. The Court believes that the obligation to informing the Commission should be considered as introduction to the implementation of the prevention principle (Stephans 2009).

International environmental law can hardly ignore the principles of prevention, precaution and sustainable development. Since the principle of prevention is proposed before the pollution, this case was originally referred to an appropriate position, because the mills had not yet started to work (Lee 2006).

The prevention principle is different from the precautionary principle. While the former is rooted in international treaties and has customary aspects, the precautionary principle in the mid-nineties was promoted from national law to international law. In fact, precautionary principle is one of the "general principles of law." As stated in the Rio Declaration 1992, where there is a serious threat or inevitable risk, the necessary measures should not be ignored (Declaration of the United Nations Conference on Environment and Development 1992).

Finally, the settlement of this case by the Court was a good opportunity to recognize the obligation of environmental impact assessment (EIA) which can be negligible for planning any activities by the States.

\section{Aerial Herbicide Spraying case, Ecuador versus Colombia (March 31, 2008)}

\section{Statement of facts}

Aerial Herbicide Spraying refers to the practice of releasing substances toxic to plants in order to destroy unwanted vegetation. This spraying often has unwanted consequences, especially when the herbicide crosses state borders, harming crops and vegetation in nations neighboring the one employing the aerial spraying practice. The United Nations has been concerned with this problem since at least 2000, when Colombia began spraying herbicides across the Colombian-Ecuadorian border to manage the illegal coca and poppy plantations. As part of the "Plan Colombia" initiative, the herbicide spraying was intended to mitigate the cocaine and heroin production in that area. Though this practice was somewhat effective in dealing with these unwanted crops, the herbicides had several negative consequences as well. Since 2008, Ecuador has made several attempts to negotiate directly with Colombia in order to stop Aerial Herbicide Spraying and ensure the well-being of Ecuador's people and nation. Unfortunately, these attempts have proved to be futile, and Ecuador has eventually turned to the ICJ for support (Plan Colombia 2008).

Government of Ecuador has submitted an application to the ICJ against the Government of Colombia based on violation of obligations under international law by Colombia which resulted in losses to people, crops, animals and the natural environment located on the border of Ecuador and will cause further damage over time (Aerial Herbicide Spraying, Application instituting proceedings 2008).

In the application, Ecuador claimed that local communities have been exposed to live with toxic substance according to their ancient traditions. They are strongly dependent on the environment and due to the extreme poverty are dependent on materials and agricultural products such as corn, coffee and other products which are necessary for their survival. On the other hand, medical care and treatment in these areas are primary and formal training is at lower levels. As a result, the Colombian Government measures on disinfecting the affected area have created significant risks to human and natural environment of the region (Esposito 2010).

Considering the spraying on their soil to be a breach of national sovereignty, Ecuador also demands compensation for its losses. In fact, many international organizations have called for the halt of Plan Colombia until it can be proven that the herbicide they are using is no longer hazardous. For the time being, several studies have indicated the deleterious effects of these chemicals. At this time, human rights violations and significant environmental concerns have served as the impetus for the resolution of this matter (Esposito 2010).

Government of Ecuador cited to "American Treaty on Pacific Settlement of Disputes (Pact of Bogotá)" which was signed by Ecuador and Colombia in 1948 to establish the ICJ jurisdiction (American Treaty on Pacific Settlement of Disputes 1948).

Therefore, Ecuador after establishing the Court's jurisdiction focused on the violation of customary and conventional rules of international law concerning the obligation of 
States to ensure that activities within their jurisdiction or control do not cause damage to the environment of other States or of areas beyond the limits of national jurisdiction. Trans-boundary damage, Sic Utere and violation of the prevention principle constitute fundamental arguments of Ecuador in the application submitted to the Court.

\section{International Court of Justice Order of September 13,2013}

On September 13, 2013, the president of the ICJ issued an Order in the case concerning Aerial Herbicide Spraying (Ecuador vs. Colombia), recording the discontinuance of the proceedings and directing the removal of the case from the Court's list. The Order of the president of the Court reads as follows:

The President of the ICJ mentioned that according to the application filed in the Registry of the Court on March 31, 2008, the Republic of Ecuador instituted proceedings against the Republic of Colombia in respect of a dispute concerning "Colombia's aerial spraying of toxic herbicides at locations near, at and across its border with Ecuador" which "has already caused serious damage to people, to crops, to animals, and to the natural environment on the Ecuadorian side of the frontier, and poses a grave risk of further damage over time" (ICJ, Summaries of Judgments, Advisory Opinions and Orders of the International Court of Justice, AERIAL HERBICIDE SPRAYING (ECUADOR v. COLOMBIA) Order of 13 September 2013) (Statute of the International Court of Justice 1945).

In addition, according to the ICJ's report, the Agent of Ecuador sent a letter to the Registry on September 12, 2013; in this letter, he had referred to Article 89 of the Rules of Court and to an agreement between the two Parties dated September 9, 2013, "that fully and finally resolves all of Ecuador's claims against Colombia" in the case, and notified the Court that his Government wished to discontinue the proceedings in the case (Aerial Herbicide Spraying (Ecuador v. Colombia), Order of 13 September 2013, ICJ Reports 2013, p. 278).

A copy of that letter was immediately communicated to the Government of Colombia, which was asked, pursuant to Article 89, paragraph 2, of the Rules of Court, to inform the Court, by a letter to be transmitted at the meeting which the president had called with the agents of the Parties for September 12, 2013, if Colombia objected to the discontinuance (Rules of the International Court of Justice 1978).

By a letter dated September 12, 2013, handed in at the above-mentioned meeting, the agent of Colombia informed the Court that his Government made no objection to the discontinuance of the case as requested by Ecuador.

According to the letters received from the Parties, the Agreement of September 9, 2013, establishes, inter alia, an exclusion zone, in which Colombia will not conduct aerial spraying operations, creates a Joint Commission to ensure that spraying operations outside that zone have not caused herbicides to drift into Ecuador and, so long as they have not, provides a mechanism for the gradual reduction in the width of the said zone.

According to the letters, the agreement sets out operational parameters for Colombia's spraying programmed, records the agreement of the two Governments to ongoing exchanges of information in that regard, establishes a dispute settlement mechanism and places on record the discontinuance by the republic of Ecuador of the proceedings instituted by its application filed on March 31, 2008 (Aerial Herbicide Spraying, Summary of the Order 2013).

\section{Judgment analysis}

One of the ways to establish the international liabilities of the States is causing damage and consequently compensation for the damage. In this case, establishing an agreement by the Parties negates the ongoing proceedings by the Court. Court's jurisdiction is optional or in other words referring the dispute to the ICJ and accepting the Court's jurisdiction is based on the will of the Parties. Therefore, by mutual agreement to resolve the matter out of the Court, this judicial body fails to proceed one of its main tasks on the development of law (Viñuales 2008).

It seems that based on the evidence presented by the applicant, by continuing the case, the Court citing to the principle 21 of Stockholm Declaration and abuse of rights principle could decide to condemn the defendant, but establishment of the agreement between the Parties provides the demands of Ecuador and replaces the Court's decision.

\section{Whaling in the Antarctic case, Australia versus Japan: New Zealand intervening (May 31, 2010)}

\section{Statement of facts}

On May 31, 2010, Government of Australia, in accordance with Article 36, paragraphs 1 and 2, Article 40 of the Statute of the Court and Article 38 of the Rules of Court (Rules of the International Court of Justice 1978), submitted to the Court an application instituting proceedings against the Government of Japan. This application insists that Japan continued pursuit of a large-scale program of whaling under the second phase of its "Japanese whale research program" under special permit in the Antarctic (JARPA II). In this context, this act considered as a breach of obligations assumed by Japan under the International Convention for the Regulation of Whaling (ICRW), as well as its other international obligations for the preservation of marine mammals and the marine environment. 
In 1982, the International Whaling Commission (IWC) adopted under Article V (l) (e) of the ICRW a moratorium on whaling for commercial purposes, fixing the maximum catch of whales to be taken in any one season at zero. This was brought into effect by the addition of paragraph 10 (e) to the Schedule to the ICRW which provides that "catch limits for the killing for commercial purposes of whales from all stocks for the 1986 coastal and the 1985-1986 pelagic seasons and thereafter shall be zero. This provision will be kept under review, based upon the best scientific advice..." (IWC Resolutions 1985, 1986).

But on the contrary to restrictions and prohibitions established by the Convention, the Japanese Government began the indiscriminate taking and killing whales in Antarctica under the pretext of carrying out its research program called the JARPA II. The full-scale JARPA II then commenced in the 2007-2008 season. Although Japan has purported to justify JARPA II by reference to the special permit provision in Article VIII of the ICRW, the scale of killing, taking and treating carried out under this program greatly outweighs any previous practice undertaken on the basis of scientific permits in the history of the IWC (Watkins 2012).

According to Article VIII of the ICRW, under which a Contracting Government may issue special permits to its nationals authorizing that national to "kill, take and treat whales for the purposes of scientific research..." (International Convention for the Regulation of Whaling 1946).

The IWC has made numerous recommendations to Japan concerning its program entitled JARPA II. It has done so against the background of earlier recommendations that special permit whaling must meet critically important research needs that it be conducted in a manner consistent with the Commission's conservation policy and ensure that the recovery of populations is not impeded; that it only be permitted in exceptional circumstances; that it be conducted using non-lethal techniques and that it ensure the conservation of whales in sanctuaries (Eighth report of the International Whaling Commission 1957).

Australia considers that in proposing and implementing JARPA II, Japan has breached and is continuing to breach its international obligations. In particular, Japan has breached and is continuing to breach the following obligations under the ICRW:

(a) The obligation under paragraph 10 (e) of the Schedule to the ICRW to observe in good faith the zero catch limit in relation to the killing of whales for commercial purposes and

(b) The obligation under paragraph 7 (b) of the Schedule to the ICRW to act in good faith to refrain from undertaking commercial whaling of humpback and fin whales in the Southern Ocean Sanctuary (Whaling in the Antarctic, application instituting proceedings 2010).

Further, Japan has breached and is continuing to breach, inter alia, the following obligations:

(a) Under the Convention on International Trade in Endangered Species of Wild Fauna and Flora (CITES), the Fundamental Principles contained in Article II in relation to "introduction from the sea" of an Annex I listed specimen other than in "exceptional circumstances," and the conditions in Article III (5) in relation to the proposed taking of humpback whales under JARPA II

And

(b) Under the Convention on Biological Diversity, the obligations to ensure that activities within their jurisdiction or control do not cause damage to the environment of other States or of areas beyond the limits of national jurisdiction (Article 3), to cooperate with other Contracting Parties, whether directly or through a competent international organization (Article 5), and to adopt measures to avoid or minimize adverse impacts on biological diversity (Article 10 (b)).

For these reasons, and reserving the right to supplement, amplify or amend the present application, Australia requests the Court to adjudge and declare that Japan is in breach of its international obligations in implementing the JARPA II program in the Southern Ocean (International Convention for the Regulation of Whaling 1946; Convention on Biological Diversity 1992; Convention on International Trade in Endangered Species of Wild Fauna and Flora 1973).

In addition, Australia requests the Court to order that Japan:

(a) Cease implementation of JARPA II;

(b) Revoke any authorizations, permits or licenses allowing the activities which are the subject of this application to be undertaken and

(c) Provide assurances and guarantees that it will not take any further action under the JARPA II or any similar program until such program has been brought into conformity with its obligations under international law (Whaling in the Antarctic, Application instituting proceedings 2010).

\section{New Zealand intervention in whaling case}

On Tuesday November 20, 2012, New Zealand, invoking Article 63 of the Statute of the Court, filed in the Registry of the ICJ a declaration of intervention in the case 
concerning whaling in the Antarctic (Statute of the International Court of Justice 1945).

To avail itself of the right of intervention conferred by Article 63 of the Statute, New Zealand relies on its "status as a party to the International Convention for the Regulation of Whaling." New Zealand contends that as a party to the Convention it has a direct interest in the construction that might be placed upon the Convention by the Court in its decision in these proceedings (Declaration Of intervention of New Zealand 2013).

In its declaration, New Zealand further explains that its intervention is directed to questions of the construction, in particular, of Article VIII of the Convention, arising in the case. That Article provides, inter alia, that "any Contracting Government may grant to any of its nationals a special permit authorizing that national to kill, take and treat whales for purposes of scientific research subject to such restrictions as to number and subject to such other conditions as the Contracting Government thinks fit..."

As noted, this Article is the subject of conflict between the Governments of Australia and Japan on whaling. According to Article 63 of the Statute, the Court considers the New Zealand intervention as an incidental proceeding. Providing the intervention declaration of the third party, Ipso facto, does not establish the third party intervention's condition in the case. It must be in the scope of Article 63 of the Statute, and such a declaration must be plausible.

The Court noted that New Zealand intervention as the third party is merely for having legal interests on interpretation of Article 8 of the Convention. Apart from this, New Zealand Government is not considered as the dispute party in the present case. Australia and New Zealand do not have necessarily the same interests. Finally, according to the provisions of Article 82 and Article 63 of Rules of the Court and because the Parties did not object to intervention of New Zealand, the Court considered the declaration of New Zealand intervention plausible as a third party (Declaration Of intervention of New Zealand 2013).

\section{Questions and the Court response}

\section{Interpretation of Article VIII, paragraph 1, of the International Convention for the Regulation of Whaling}

The interpretation and application of Article VIII of the Convention is central to the current case. In the view of the Court, while this Article gives discretion to a State Party to the Convention to reject the request for a special permit or to specify the conditions under which a permit will be granted, the question of whether the killing, taking and treating of whales pursuant to a requested special permit are for purposes of scientific research cannot depend simply on that State's perception.

In order to ascertain, in particular, whether a programmer's use of lethal methods is "for purposes of" scientific research, the Court considers whether the elements of such a programmer's design and implementation are reasonable in relation to its stated research objectives. As shown by the arguments of the Parties, these elements may include: decisions regarding the use of lethal methods; the scale of the programmer's use of lethal sampling; the methodology used to select sample sizes; a comparison of the target sample sizes and the actual take; the time frame associated with a program; the programmer's scientific output and the degree to which a program coordinates its activities with related research projects (Whaling in the Antarctic, Summary of the Judgment 2014).

\section{Application of Article VIII, paragraph 1, to JARPA II}

The Court finds that JARPA II can broadly be characterized as "scientific research." It then examines whether its design and implementation are reasonable in relation to achieving the programmer's stated research objectives. Examining Japan's decisions regarding the use of lethal methods, the Court finds no evidence of any studies of the feasibility or practicability of non-lethal methods, either in setting the JARPA II sample sizes or in later years in which the program has maintained the same sample size targets. The Court also observes a significant gap between the JARPA II target sample sizes and the actual take. In the view of the Court, the gap between the target sample sizes for fin and humpback whales in the JARPA II research plan and the actual take of these two species undermines Japan's argument that the objectives relating to ecosystem research and multi-species competition justify a larger target sample size for minke whales, as compared to that in JARPA. The Court notes that there are three additional aspects of JARPA II which cast further doubt on its characterization as a program for purposes of scientific research: the openended time frame of the program, its limited scientific output to date and the lack of cooperation between JARPA II and other national and international research programs in the Antarctic Ocean [Japanese whale research program (JARPA/JARPAII) 2013].

Taken as a whole, the Court considers that JARPA II involves activities that can broadly be characterized as scientific research, but that "the evidence does not establish that the programmer's design and implementation are reasonable in relation to achieving its stated objectives." The Court concludes that the special permits granted by Japan for the killing, taking and treating of whales in connection with JARPA II are not "for purposes of scientific research" pursuant to Article VIII, paragraph 1, of 
the Convention (Whaling in the Antarctic, Summary of the Judgment 2014).

\section{Examination of alleged violations of the Schedule}

The Court turns next to the implications of that conclusion, in light of Australia's contention that Japan has breached several provisions of the Schedule. The Court therefore concludes that Japan has violated: (1) the moratorium on commercial whaling in each of the years during which it has set catch limits above zero for minke whales, fin whales and humpback whales under JARPA II; (2) the factory ship moratorium in each of the seasons during which fin whales were taken, killed and treated under JARPA II and (3) the prohibition of commercial whaling in the Southern Ocean Sanctuary in each of the seasons during which fin whales have been taken under JARPA II.

The Court then turns to Australia's allegation that Japan violated paragraph 30 of the Schedule, which requires that Contracting Governments provide the secretary to the IWC with proposed scientific permits before they are issued and in sufficient time to allow the Scientific Committee to review and comment on them. In this regard, the Court observes that Japan submitted the JARPA II research plan for review by the Scientific Committee in advance of granting the first permit for the program and also submitted for review all subsequent permits. The Court also finds that the JARPA II research plan sets forth all the information specified by that provision. For these reasons, the Court considers that Japan has met the requirements of paragraph 30 as far as JARPA II is concerned Convention (Whaling in the Antarctic, Summary of the Judgment 2014).

\section{Remedies}

The Court observes that JARPA II is an ongoing program. Under these circumstances, measures that go beyond declaratory relief are warranted. The Court therefore orders that Japan revoke any extant authorization, permit or license to kill, take or treat whales in relation to JARPA II, and refrain from granting any further permits under Article VIII, paragraph 1 , of the Convention, in pursuance of that program. The Court sees no need to order the additional remedy requested by Australia, which would require Japan to refrain from authorizing or implementing any special permit whaling which is not for purposes of scientific research within the meaning of Article VIII, since that obligation already applies to all States Parties' Convention (Whaling in the Antarctic, Summary of the Judgment 2014).

\section{Court judgment}

The International Court of Justice, the principal judicial organ of the United Nations, on March 31, 2014, has rendered its judgment in the case concerning whaling in the Antarctic.

The Court finds that Japan's whaling program in the Antarctic (JARPA II) is not in accordance with three provisions of the Schedule to the International Convention for the Regulation of Whaling.

In that judgment, which is final, without appeal and binding on the Parties, the Court finds that the special permits granted by Japan in connection with JARPA II do not fall within the provisions of Article VIII, paragraph 1, of the International Convention for the Regulation of Whaling.

The Court finds that Japan, by granting special permits to kill, take and treat fin, humpback and Antarctic minke whales in pursuance of JARPA II, has not acted in conformity with its obligations under paragraph 10 (e) of the Schedule to the International Convention for the Regulation of Whaling.

The Court finds that Japan has not acted in conformity with its obligations under paragraph 10 (d) of the Schedule to the International Convention for the Regulation of Whaling in relation to the killing, taking and treating of fin whales in pursuance of JARPA II; finds that Japan has not acted in conformity with its obligations under paragraph 7 (b) of the Schedule to the International Convention for the Regulation of Whaling in relation to the killing, taking and treating of fin whales in the "Southern Ocean Sanctuary" in pursuance of JARPA II; finds that Japan has complied with its obligations under paragraph 30 of the Schedule to the International Convention for the Regulation of Whaling with regard to JARPA II and decides that Japan shall revoke any extant authorization, permit or license granted in relation to JARPA II and refrain from granting any further permits in pursuance of that program Convention (Whaling in the Antarctic, Summary of the Judgment 2014).

\section{Judgment analysis}

In this case, the Court investigated applicant's requests completely and answered all questions carefully. By proving this point that Japan has refused to implementation of its obligations under the International Convention for the Regulation of Whaling, the judgment represents one of the positive functions of the Court in this field.

The Court pays special attention to the three conventions including International Convention for the Regulation of Whaling (1946), Convention on Biological Diversity (1992) and Convention on International Trade in 
Endangered Species of Wild Fauna and Flora (1973), which means the Court gives great importance to its jurisdiction on environmental issues. In this case, the Court takes an Erga Omnes approach.

Where environmental conventions such as International Convention for the Regulation of Whaling (1946); Convention on Biological Diversity (1992); Convention on International Trade in Endangered Species of Wild Fauna and Flora (1973) and more do not have adequate executive legal sanctions, the ICJ judgments could be one of the most powerful tools for the implementation of these conventions. These judgments can cover these gaps properly.

On the other hand, in the above case, New Zealand intervention as the third party was accepted. It showed the strengths of the Court, because the third intervention in the cases of the Court cannot develop further laws regarding the international procedure.

\section{Certain activities carried out by Nicaragua in the border area case, Costa Rica versus Nicaragua (November 18, 2010)}

\section{Statement of facts}

By an application filed in the Registry of the ICJ on November 18, 2010, the Government of Costa Rica instituted proceedings against the Government of Nicaragua in the case concerning certain activities carried out by Nicaragua in the border area (Costa Rica vs. Nicaragua) for "the incursion into, occupation of and use by Nicaragua's army of Costa Rican territory." Costa Rica alleged breaches by Nicaragua of its obligations toward Costa Rica under a number of treaty instruments and other applicable rules of international law.

Costa Rica states in its application that "by sending contingents of its armed forces to Costa Rican territory and establishing military camps therein, Nicaragua is not only acting in outright breach of the established boundary regime between the two Governments, but also of the core founding principles of the United Nations, namely the principles of territorial integrity and the prohibition of the threat or use of force against any state in accordance with Article 2, paragraph 4, of the Charter (Charter of the United Nations 1945); also endorsed as between the Parties in Articles 1, 19 and 29 of the Charter of the Organization of American States" (Charter of the Organization of American States 1948).

Costa Rica contends in the said application that "Nicaragua has, in two separate incidents, occupied the territory of Costa Rica in connection with the construction of a canal across Costa Rican territory from the San Juan River to Laguna los Portillos (also known as Harbor Head
Lagoon) and certain related works of dredging on the San Juan River"; it states that during the first incursion, which occurred on or about October 18, 2010, Nicaragua was reported "felling trees and depositing sediment from the dredging works on Costa Rican territory"; it adds that "after a brief withdrawal, on or about November 1, 2010, a second contingent of Nicaraguan troops entered Costa Rican territory and established a camp"; Costa Rica maintains that "this second incursion has resulted in the continuing occupation by armed Nicaraguan military forces of an initial area of around $3 \mathrm{~km}^{2}$ of Costa Rican territory, located at the northeast Caribbean tip of Costa Rica," but that "evidence shows that Nicaraguan military forces have also ventured further inside Costa Rican territory, to the south of that area"; it contends that Nicaragua has "also seriously damaged that part of Costa Rican territory under its occupation"(Certain activities carried out by Nicaragua in the border area, Application instituting proceedings 2010).

Costa Rica states that "Nicaragua is currently destroying an area of primary rainforests and fragile wetlands on Costa Rican territory (listed as such under the Ramset Convention's List of Wetlands of International Importance) for the purpose of facilitating the construction of a canal through Costa Rican territory, intended to deviate the waters of the San Juan River from its natural historical course into Laguna los Portillos (the Harbor Head Lagoon)".

Costa Rica contends that it has regularly protested to Nicaragua and called on it not to dredge the San Juan River "until it can be established that the dredging operation will not damage the Colorado River or other Costa Rican territory," but that Nicaragua has nevertheless continued with its dredging activities on the San Juan River and that it "even announced on November 8, 2010, that it would deploy two additional dredges to the San Juan River", one of which is reportedly still under construction.

Costa Rica asserts that Nicaragua's statements demonstrate "the likelihood of damage to Costa Rica's Colorado River, and to Costa Rica's lagoons, rivers, herbaceous swamps and woodlands", the dredging operation posing more specifically "a threat to wildlife refuges in Laguna Maquenque, Barra del Colorado, Corredor Fronterizo and the Tortuguero National Park."

Costa Rica refers to the adoption on November 12, 2010, of a resolution of the Permanent Council of the Organization of American States, welcoming and endorsing the recommendations made by the secretary-general of that organization in his report of November 9, 2010 (Resolution of the Permanent Council of the Organization of American States 2010); and it states that the Permanent Council called on the Parties to comply with those recommendations, in particular that requesting "the avoidance 
of the presence of military or security forces in the area where their existence might rouse tension"; Costa Rica asserts that Nicaragua's "immediate response to the resolution of the Permanent Council of the Organization of American States was to state its intention not to comply with it" and that Nicaragua has "consistently refused all requests to remove its armed forces from the Costa Rican territory in Isla Portillos."

In particular, the Court is requested to adjudge and declare that, by its conduct, Nicaragua has breached:

(a) The obligation not to use the San Juan River to carry out hostile acts;

(b) The obligation not to damage Costa Rican territory;

(c) The obligation not to artificially channel the San Juan River away from its natural watercourse without the consent of Costa Rica;

(d) The obligation not to prohibit the navigation on the San Juan River by Costa Rican nationals;

(e) The obligation not to dredge the San Juan River if this causes damage to Costa Rican territory (including the Colorado River);

(f) The obligations under the Ramsar Convention on Wetlands;

(g) The obligation not to aggravate and extend the dispute by adopting measures against Costa Rica, including the expansion of the invaded and occupied Costa Rican territory or by adopting any further measure or carrying out any further actions that would infringe Costa Rica's territorial integrity under international law.

On November 18, 2010, having filed its application, Costa Rica also submitted a request for the compensation and the indication of provisional measures, pursuant to Article 41 of the Statute of the Court and Articles 73-75 of the Rules of Court (Statute of the International Court of Justice 1945; Rules of the International Court of Justice 1978).

Costa Rica believes that by the continued presence of military forces leads to violation of the territorial integrity and damage to ecosystems and protected areas of Costa Rica and this is not acceptable. Costa Rica declare that if the Court does not take the practical and urgent initiative in respect of provisional measures, the next step of Costa Rica might lead to armed conflict in the region and affect the facts of the present proceedings before the Court. Consequently, the Court considers it necessary to issue provisional measures to protect their sovereignty, territorial integrity and nonintervention in the rights of the river San Juan as well as to support protected lands and ecological areas and Colorado River water flow. Costa Rica requests the Court to order Nicaragua to withdraw its military forces from territory of the country, to refuse digging canals in the territory of the country and to stop cutting down trees and destroying vegetation and dredging the River. The Nicaraguan military presence in its territory in addition to violating the sovereign rights of the State, is serious threat to forests and protected areas; also dredging of the San Juan River puts the flow of the Colorado River water at risk, and Nicaragua should not be allowed to present Costa Rica and the Court with a fait accompli, by digging canals (Certain activities carried out by Nicaragua in the border area, Summary of the Order 2013a).

\section{Provisional measures of International Court of Justice in case concerning certain activities carried out by Nicaragua in the border area}

By an Order of March 8, 2011, ICJ indicated the following provisional measures to both Parties:

1. Each Party shall refrain from sending to, or maintaining in the disputed territory, including the caño, any personnel, whether civilian, police or security;

2. Costa Rica may dispatch civilian personnel charged with the protection of the environment to the disputed territory, including the caño, but only in so far as it is necessary to avoid irreparable prejudice being caused to the part of the wetland where that territory is situated; Costa Rica shall consult with the secretariat of the Ramsar Convention in regard to these actions, give Nicaragua prior notice of them and use its best endeavors to find common solutions with Nicaragua in this respect;

3. Each party shall refrain from any action which might aggravate or extend the dispute before the Court or make it more difficult to resolve;

4. Each party shall inform the Court as to its compliance with the above provisional measures.

By an Order of November 22, 2013, the Court indicated provisional measures in the case concerning certain activities carried out by Nicaragua in the border area (Costa Rica vs. Nicaragua) and, with the confirmation of the contents of provisional measures on March 8, 2011, stated that Nicaragua should refrain from any dredging and other activities in the disputed area, especially from carrying out any operation in two new artificial waterways. Nicaragua should fill the canals within 2 weeks and within a week after its completion and submit a report containing all the details of the Order to the Court. Nicaragua should also remove all Nicaraguan personnel, whether civilian, police and security, from the area and prevent them from entering. Also defendant should remove all private entities under its jurisdiction or control from the area and prevented from entering. On the other hand, Costa Rica, after consultation with the secretariat of the Ramsar Convention and after 
prior notification to Nicaragua, can take appropriate actions regarding the new waterway, to the extent that it is essential to avoid irreversible damage to the environment and of course, in adopting such measures, should refrain from imposing any kind of adverse effects on the San Juan River (Certain activities carried out by Nicaragua in the border area, Indication of provisional measures 2013b).

The Parties should inform the Court every 3 months regularly regarding to compliance with the Court Orders. The Court also stated that the provisional measures are rights claimed by the applicant who should be acceptable and in this case there is a link between the case before the Court and requested provisional measures.

In the present case, Costa Rica attempts to protect its sovereignty on Isla portillos, territorial integrity and its environmental areas. Thus, the rights claimed by Costa Rica are acceptable, and there is a link between Costa Rica rights and the requested provisional measures which are stopping any activity in the waterways of Nicaragua, removal of all personnel, equipment or private entities under its jurisdiction and control. These provisional measures are allowing Costa Rica to take remedial measures in the region. However, the Court did not establish any link between the rights claimed by Costa Rica and the fourth request that "each party shall inform the Court about complying with all provisional measures issued by the Court." In the opinion of the Court, the recent application is not intended to protect the rights of Costa Rica, but seeks to ensure compliance with all provisional measures issued by the Court.

In opinion of the Court, when there is a real and immediate risk of the occurrence of irreversible damage, due to the length, width and location of the ditch, there is a risk of connecting the canals to the Caribbean Sea whether as a result of natural reasons or as a result of human actions or both. On the other hand, changing the waterways of San Juan River is associated with irreversible damage to the rights claimed by Costa Rica (Certain activities carried out by Nicaragua in the border area, Indication of provisional measures 2013b).

\section{Construction of a road in Costa Rica along the San Juan River case, Nicaragua versus Costa Rica (December 21, 2011)}

\section{Statement of facts}

The Republic of Nicaragua on December 21, 2011, submitted a dispute to the Court in accordance with the provisions of Article 36, paragraph 1, Article 40 of the Statute and Article 38 of the Rules of Court (Statute of the International Court of Justice 1945; Rules of the International
Court of Justice 1978). Jurisdiction exists by virtue of Article XXXI of the American Treaty on Pacific Settlement signed in Bogota on April 30, 1948 (Pact of Bogota). Both the Republic of Nicaragua and the Republic of Costa Rica are Parties to the Pact of Bogota (American Treaty on Pacific Settlement of Disputes 1948). The claim is brought against the Republic of Costa Rica for violations of Nicaraguan sovereignty and major environmental damage on its territory.

The most immediate threat to the river and its environment is posed by Costa Rica's construction of a road running parallel and in extremely close proximity to the southern bank of the river, extending for a distance of at least $120 \mathrm{~km}$, from Los Chiles in the west to delta in the east (Reports of International Arbitral Awards 2007).

These works have already resulted in dumping of substantial volumes of sediments into the river-soil, uprooted vegetation and felled trees-produced by the clearing and leveling of the land that now serves as the road bed. Further, the felling of trees and the removal of topsoil and vegetation close to the river bank facilitate erosion and the leaching of even greater amounts of sediments into the river. The sedimentation of the river poses a clear and imminent danger to water quality, to aquatic life (including several endangered species) and to rare and diverse fauna and flora that populate the river banks on both sides (Central American Institute for studies in toxic substances, technical reports 2009).

Nicaragua has an impressive wealth of biodiversity consisting of hundreds of species of flora and fauna which thrive in ecosystems throughout the country. The area including and surrounding the San Juan River is especially rich, and Nicaragua has invested considerable efforts in crafting and enforcing the laws and regulations necessary to protect and conserve these delicate ecological areas.

Costa Rica's new road is the most recent, and currently the most urgent, threat to the San Juan de River and its ecosystem. Customary international law in particular the obligation in a trans-boundary context not to cause harm to neighboring States and its corollary obligation under general international law to notify and consult with a neighboring State in regard to activities that risk damaging that State's territory, and to undertake an environmental impact assessment, where there is a risk that the proposed activity may have a significant adverse effect in a trans-boundary context (Construction of a Road in Costa Rica along the San Juan River, Application instituting proceedings 2011).

On the basis of the foregoing statement of facts and law, Nicaragua, while reserving the right to supplement, amend or modify this application, requests the Court to adjudge and declare that Costa Rica has breached:

(a) Its obligation not to damage Nicaraguan territory; 
(b) Its obligations under general international law and the relevant environmental conventions and instruments, including the Ramsar Convention on Wetlands, the Agreement over the Border Protected Areas between Nicaragua and Costa Rica, the Convention on Biological Diversity, the Convention for the Conservation of the Biodiversity and Protection of the Main Wild Life Sites in Central America and Convention Concerning the Protection of the World Cultural and Natural Heritage, adopted by the General Conference of UNESCO in 1972 and Declaration of the United Nations Conference on Human Environment, June 16, 1972 (Convention on Wetlands of International Importance especially as Waterfowl Habitat 1971; Agreement over the Bordet Protected Areas between Nicaragua and Costa Rica 1990; Convention on Biological Diversity 1992; Convention for the Conservation of the Biodiversity and Protection of the Main Wild Life Sites in Central America 1992; Convention Concerning the Protection of the World Cultural and Natural Heritage 1972; Declaration of the United Nations Conference on Human Environment 1972).

Nicaragua requests the Court to adjudge and declare that Costa Rica must:

(a) Restore the situation to the status quo ante.

(b) Pay for all damage caused including the costs added to the dredging of the San Juan River.

(c) Not undertake any future development in the area without an appropriate trans-boundary environmental impact assessment and that this assessment must be presented in a timely fashion to Nicaragua for its analysis and reaction.

\section{Request presented by Nicaragua for the indication of provisional measures in case concerning construction of a road in Costa Rica along the San Juan River}

The Court notes that by two separate Orders dated April 17, 2013, the Court joined the proceedings in the case concerning the construction of a road in Costa Rica along the San Juan River (Nicaragua vs. Costa Rica) and certain activities carried out by Nicaragua in the border area (Costa Rica vs. Nicaragua).

ICJ rejected the request for provisional measures on December 13, 2013. Nicaraguan submitted a dispute to the Court on December 22, 2011. The claim is brought against the Republic of Costa Rica for violations of Nicaraguan sovereignty by building a road near the border between the two countries over the San Juan River and environmental damage to the land, river and agricultural and industrial activities. In addition, Nicaragua requests the Court "to decide independently, whether the circumstances of the case demands to issue provisional measures or not." On March 2013, the Court declared that according to the case circumstances, it does not require issuing provisional measures by the Court.

Then, Costa Rica requested the Court to issue a provisional measures based on the new circumstances on October 11, 2013. Given that the Court simultaneously deals with the case of Costa Rica against Nicaragua and the case of Nicaragua against Costa Rica and also Costa Rica's request for indication of provisional measures in the case of Costa Rica against Nicaragua, applicant requested the Court to consider two provisional measures simultaneously, which faced with opposition the defendant and the Court. Nicaragua claimed that Costa Rica always refuses to give appropriate information on the road construction and denies the obligation to provide information on environmental impact assessment of the activities. With the onset of the rainy season, the defendant still has not given the necessary information to the applicant and has not taken an action to reduce the risk of damage to the river and shipping in the surrounding environment and the health and welfare of the inhabitants (Construction of a road in Costa Rica along the San Juan River, Summary of the Order 2013).

Hence, Nicaragua requests the Court to announce Costa Rica to provide them with the information relating to environmental impact assessment and all technical reports and assessments related to reducing of environmental damage to the river, immediately and unconditionally, to eliminate or reduce the risk of sediment pouring into the river, and to order Costa Rica not to continue road construction activities until the Court judgment on nature of the dispute is passed. The Court stated that it will issue provisional measures in the event that at least the rights of the petitioner's claim are plausible and on this stage of the proceedings it is not necessary to establish that the rights claimed by the applicant are approved certainly.

Rights claimed by Nicaragua include remaining immune from trans-boundary damage that is rooted in the right of a state sovereignty and territorial integrity. According to the Court, the obligation that "activities under the jurisdiction or control of States should respect the environment and jurisdiction of other States outside their national territories" is a part of the corpus of international environmental law. Also according to the latest Government policy, environmental impact assessment assuming that there is a risk of significant damage caused by industrial activity is an obligation in public international law. So, in that respect, Nicaragua's claims to be immune from transboundary environmental damage is Plausible. After 
considering the request of Nicaragua based on indicating provisional measures, the Court stated that the first request about providing the information related to environmental impact assessment and all related technical reports and assessments, immediately and unconditionally, is one of the claims made by applicant in consideration of the substantive dispute. In this context, the Court ordered that such demand leads to judgments without considering the nature of the case. About other requests of Nicaragua, the Court stated that although there is a link between the main case and its request, however, according to the evidence, Nicaragua failed to prove a significant risk due to increase in river sediments.

According to the Court, such a small amount of sediment will not have a significant impact on the river in the near future and no evidence has been provided yet to show that this amount of sediment in the river has long-term effects. While applicant did not clear to the Court that what is the impact of road construction on the environment around the river, thus, according to the Court, Nicaragua failed to prove a real and imminent risk that will cause irreversible damage to their rights. Furthermore, Costa Rica during proceedings declares that it is obliged to avoid the activities that cause eligible damage and takes measures to prevent such damage (Construction of a road in Costa Rica along the San Juan River, Summary of the Order 2013).

\section{Analysis of the above cases (certain activities carried out by Nicaragua in the border area and construction of a road in Costa Rica along the San Juan River)}

In the case concerning certain activities carried out by Nicaragua in the border area (Costa Rica vs. Nicaragua), the Costa Rican Government seeks to protect its sovereignty on the border, the right to territorial integrity and environmental protection of areas under its sovereignty. Given that the rights claimed by Costa Rica were plausible, the Court proceeds to issue provisional measures.

But in the case of construction of a road in Costa Rica along the San Juan River (Nicaragua vs. Costa Rica), Nicaraguan Government seeks to protect its sovereignty over the border, prevent environmental degradation of the San Juan River and compensate for damage incurred by Costa Rica. The Court rejected the rights claimed by Nicaragua and even the request for issuance of provisional measures. It seems that the case of construction of a road in Costa Rica along the San Juan River (Nicaragua vs. Costa Rica) is a counterclaim, since Nicaragua, shortly after the case of certain activities carried out by Nicaragua in the border area, files a dispute against Costa Rica. In fact, a counterclaim is a dispute that applicant submits against defendant dispute. These types of disputes may serve to respond to the case or in addition to that obligate defendant to pay or do something. In other words, the defendant has the right to file a dispute against claim of the applicant.

Nicaragua dispute is a counterclaim, because it has many connections with the main case and both Governments considered their sovereignty and environment at risk.

Due to the above cases, it seems that not only Costa Rica and Nicaragua, but the majority of States consider the environment when their sovereignty is at risk. In the context of environmental protection, the majority of States seek to restore their rights and interests including sovereignty and territorial integrity of their own in international courts such as the International Court of Justice. Thus, environmental protection can be a strong reason for submitting a dispute in international courts.

In the domain of provisional measures, the ICJ has recently moved forward the legal effects of the aforementioned measures in connection with the importance of prevention of irreparable harm for the protection of people in territory and of cultural and spiritual heritage, altogether (Dispute regarding navigational and related rights 2009). It can be more appropriately examined within the framework of the autonomous legal régime of provisional measures of protection. Non-compliance with such measures entails an additional ground of liability.

\section{Conclusion}

As stated, ICJ has done many efforts to settle international environmental disputes, although there are cases still remain under investigation in the Court. However, the ever-increasing growth of international tribunals and courts has not resulted in considerable development of international environmental law, nor has improved the position of international environmental protection. International community for preventing further destruction of environment specially natural resources and achieving environmental justice should review the available options to improve the international judicial system.

As a result of considering above-mentioned international judgments and judicial precedents from the case of pulp mills on the River Uruguay (Argentina vs. Uruguay) to the case of construction of a road (Costa Rica vs. Nicaragua), it appears that:

First, ICJ still retains its traditional approach regarding the priority of States' national sovereignty over Erga omnes obligations, at least until the ICJ advisory opinion on the legality of the threat or use of nuclear weapons in 1996 and International Court of Justice's contentious ruling on Gabcíkovo-Nagymaros case in 1997. Even creation of a 
special chamber for environmental matters could not save the Court, from its traditional approach arising from public international law and mutual interests of States (Gabcíkovo-Nagymaros project 1997; Legality of the threat or use of nuclear weapons 1996).

Second, the recent cases in ICJ, like whaling in the Antarctic in 2010 and construction of a road in 2011, have confronted the Court with an opportunity to contribute to the development of international environmental law through strong inference of the rules and principles of international environmental law and, in particular, Erga omnes obligations and toward all rules.

As a result, the ICJ as the principal judicial organ of the United Nations could have a major role in the development of international environmental law, but failed to do this important task properly.

Among the applicable solutions which provided guidelines for legal gaps and existing inefficiencies in this context are:

- Acceptance of the role of Erga omnes obligations in settlement of international environmental law disputes can be one of the most essential elements for improving the international environmental law.

- International main actors such as States and recent actors such as international organizations, including non-governmental organizations (NGOs), should apply the international environmental law principles in their political and economic procedures.

- With regard to the validity of global decisions in the field of environment and principles and concepts of international environmental law, ICJ should recognize the States' liability based on the new issues such as precautionary principle, prevention principle and other principles in its judgments.

Acknowledgments The authors are thankful to Dr. Farhad Dabiri (Islamic azad University) for his valuable remarks and suggestions, which have contributed to this paper significantly.

\section{References}

Aerial Herbicide Spraying (2008) Application instituting proceedings (Ecuador v. Colombia). Int Court Justice Plead 10. http://www. icj-cij.org

Aerial Herbicide Spraying (2013) Summary of the order of 13 September (Ecuador v. Colombia). Int Court Justice, General list No. 138. http://www.icj-cij.org

Agreement Over the Bordet Protected Areas Between Nicaragua and Costa Rica (1990) International System of Protected Areas for Peace [SI-A-PAZ] Agreement. https://treaties.un.org/home.aspx

American Treaty on Pacific Settlement of Disputes (1948) Pact of Bogotá. Signed at Bogotá. https://treaties.un.org/home.aspx

Avgerinopoulou D (2003) The role of the international judiciary in the settlement of environmental disputes and alternative proposals for strengthening international environmental adjudication. Prepared for global environmental governance, the PostJohannesburg Agenda, Yale Center for Environmental Law and Policy New Haven, CT:12. https://treaties.un.org/home.aspx

Central American Institute for Studies in Toxic Substances (2009) Technical reports series 6: imports of pesticides in Costa Rica, period 1977-2006. 11. https://treaties.un.org/home.aspx

Certain Activities Carried Out by Nicaragua in the Border Area (2010) Application instituting proceedings filed in the Registry of the Court (Costa Rica v. Nicaragua). http://www.icj-cij.org

Certain Activities Carried Out by Nicaragua in the Border Area (2013) Request presented by Costa Rica and Nicaragua for the indication of provisional measures (Costa Rica v. Nicaragua). Int Court Justice 1-6. http://www.icj-cij.org

Certain Activities Carried Out by Nicaragua in the Border Area (2013) Summary of the Order of 22 November (Costa Rica v. Nicaragua). Advis Opin Order Int Court Justice 1-3. http://www. icj-cij.org

Charter of the Organization of American States (1948) Signed in Bogotá. www.oas.org

Charter of the United Nations (1945) San Francisco. www.un.org/en/ documents/charter

Construction of a Road in Costa Rica along the San Juan River (2011) Application instituting proceedings (Nicaragua v. Costa Rica). 1-127. http://www.icj-cij.org

Construction of a Road in Costa Rica Along the San Juan River (2013) Summary of the Order of 13 December (Nicaragua v. Costa Rica). Advis Opin Order Int Court Justice 1-3. http:// www.icj-cij.org

Convention Concerning the Protection of the World Cultural and Natural Heritage (1972) Adopted by the General Conference of UNESCO. https://treaties.un.org/home.aspx

Convention for the Conservation of the Biodiversity and Protection of the Main Wild Life Sites in Central America (1992). https:// treaties.un.org/home.aspx

Convention on Biological Diversity (1992) Rio de Janeiro. https:// treaties.un.org/home.aspx

Convention on International Trade in Endangered Species of Wild Fauna and Flora (1973) Washington. https://treaties.un.org/ home.aspx

Convention on Wetlands of International Importance Especially as Waterfowl Habitat (1971) Ramsar, as amended by the Paris Protocol of December 1982 and Regina Amendments 28 May 1987. https://treaties.un.org/home.aspx

Declaration of Intervention of New Zealand (2013) Whaling in the Antarctic (Australia v. Japan: New Zealand Intervening). Int Court Justice. http://www.icj-cij.org

Declaration of the United Nations Conference on Environment and Development (1992). https://treaties.un.org/home.aspx

Declaration of the United Nations Conference on Human Environment (1972). https://treaties.un.org/home.aspx

Dispute Regarding Navigational and Related Rights, Costa Rica v. Nicaragua (2009) I.C.J. Reports: 213. http://www.icj-cij.org

Eighth report of the International Whaling Commission (1957) London. http://www.iwcoffice.org/index.php?ciD=1882\&cType= document

Esposito R (2010) The ICJ and the future of transboundary harm disputes: a preliminary analysis of the case concerning aerial herbicide spraying (Ecuador v. Colombia). Pace Int Law Rev Online Companion 2(1):7-20

Gabcíkovo-Nagymaros Project, Hungary vs. Slovakia (1997) I. C. J. reports: 41. http://www.icj-cij.org

Gross L (1972) Review of the role of the International Court of Justice. Am J Int Law 66:479-490

International Convention for the Regulation of Whaling (1946). https://treaties.un.org/home.aspx 
IWC Resolution (1985) First resolution on special permits

IWC Resolution (1986) Second resolution on special permits for scientific research. Both adopted by consensus. http://www. iwcoffice.org/resolutions

Japanese Whale Research Program, JARPA/JARPAII (2013) Scientific contribution. The Institute of Cetacean Research: Toyomicho 4-5: Chuo-ku: Tokyo 104-0055. http://www.icrwhale.org

Lee MK (2006) The Uruguay paper pulp mills dispute: Highlighting the growing importance of NGOs and public protest in enforcement of international environmental law. Sustain Dev Law Policy J 7(1, 24):71-73

Legality of the Threat or Use of Nuclear Weapons (1996) Advisory opinion of 8 July 1996. I. C. J. reports 1996: 241-242. http:// www.icj-cij.org

Merkouris P (2010) Case concerning pulp mills on the River Uruguay (Argentina v. Uruguay). University of Groningen Of environmental impact assessments and phantom experts, The Hague Justice Portal: 10. http://ssrn.com/abstract $=2378882$

Plan Colombia (2008) United States Government Accountability Office (GAO), GAO-09-71: counternarcotics aid to Colombia. www.gao.gov/new.items/d0971

Plator Z (1994) A theory and short history of environmental law. Loyola Los Angel Law Rev 27:1995

Pulp Mills on the River Uruguay, Argentina v. Uruguay (2006a) Application instituting proceedings: 9. www.icj-cij.org

Pulp Mills on the River Uruguay, Argentina v. Uruguay (2006b) Indication of provisional measures. Order of 13 July 2006: 87. www.icj-cij.org

Pulp Mills on the River Uruguay, Argentina v. Uruguay (2010) Summary of the Judgments: 25-47. www.icj-cij.org

Reports of International Arbitral Awards (2007) First award under the Convention between Costa Rica and Nicaragua of 8 April 1896 for the demarcation of the boundary between the two Republics. United Nations, XXVIII:215-222

Resolution of the Permanent Council of the Organization of American States (2010) CP/RES.978 (1777/10). Situation in the border area between Costa Rica and Nicaragua
Rules of the International Court of Justice (1978). https://treaties.un. org/home.aspx

Salmenkari T (2007) Direct democracy in an environmental movement: Argentine Asambleas in the Uruguay River pulp mill controversy. El Norte Finn J Lat Am Stud 2:4-5

Sands P (2003) Principles of international environmental law. Cambridge University Press, Cambridge, p 55

Sands P (2008) Litigating environmental disputes: Courts, Tribunals and the progressive development of international environmental law. Glob Forum Int Invest (OECD) 6. www.oecd.org/ investment/gfi-7

Statute of the International Court of Justice (1945). https://treaties.un. org/home.aspx

Statute of the River Uruguay (1975) United Nations treaty series (UNTS). 1295(I-21425):340-347. https://treaties.un.org/home. aspx

Stephans T (2009) International courts and environmental protection. Cambridge University Press, Cambridge, pp 187-190

Thirlway H (2010) The law and procedure of the International Court of Justice. Oxf J Br Yearb Int Law 81(1):13-15

Viñuales J (2008) The contribution of the International Court of Justice to the development of international environmental law: a contemporary assessment. 32 Fordham Int'L L J 232:23. https:// treaties.un.org/home.aspx

Waldock CHM (1948) Forum prorogatum or acceptance of a unilateral summons to appear before the international court. Int Law Q 2:377-391

Watkins C (2012) Whaling in the Antarctic: case analysis and suggestions for the future of Antarctic Whaling and stock management. New York Int Law Rev 25:1-4. http://ssrn.com/ abstract $=2035631$

Whaling in the Antarctic (2010) Application instituting proceedings (Australia v. Japan). Filed in the Registry of the Court. http:// www.icj-cij.org

Whaling in the Antarctic, Australia v. Japan: New Zealand Intervening (2014) International Court of justice summary of the judgment. 51-246. http://www.icj-cij.org 